\title{
水産情報とGIS
}

\author{
為石 日出生*
}

\section{Fisheries Information and GIS}

\author{
Hideo TAMEISHI*
}

\begin{abstract}
Forecasting fishing ground is the most important for planned fishing operation. GIS is one of the most powerful tools for the purpose, but has not been applied so much. It is essential for the forecasting to treat multidimensional information of fisheries, such as condition of resources, environment of fishing ground, effect of economy, and others. The forecasting based on GIS always includes other manifold factors: for examples, a fishing ground occurs under a complicated influence between biological factors and physical and chemical environment of sea.
\end{abstract}

Key words: Forecast of fishing ground, Fishereis informaton, Oceanographic characteristic, Fish way, Warm streamer

\section{1.はじめに（漁場予測のGIS）}

水産情報のGISは，漁場を予測するためのGIS と言って も過言ではない。 なぜなら, 漁場予測は, 資源の状態・漁 場海洋環境・経済性を加味した総合的な水産情報により可 能となるからである，また，資源管理するためにも，漁場 予測による計画的な操業が最も重要な要因と考えられるこ とも大きな理由である.ささらに，漁場予測のGISとしての 要素は, 魚類という生物要因や海という物理化学環境要因 が複雑に影響しているため, きわめて多岐にわたるもので ある。ここで，その要因を説明する前に，一般的に漁場予 測に関して魚の生態がどのようなものであるか, 最小限の 知見を説明する.

日本近海は, 黒潮と親潮がぶつかり合う前線漁場の一つ で，渦や潮境がよく発達し魚群が集まりやすい条件を作っ ている. 黒潮系や親潮系の暖寒両魚種が集まるため漁獲量 が多く, この海域での生産量は, 全世界の15\%を占める世 界の四大漁場の一つである。

黒潮はフィリピンや台湾沖からカッオやキハダ, カジキ 等のマグロ類などを日本近海へ運んでくる．また，日本近 海の表層性回遊魚であるアジ, サバ, イワシ, スルメイカ, サンマ,ブリなどは, 産卵に必要な温度を有している黒潮 水域へ, 秋から冬にかけて南下し, 海藻や流れ物に産卵す る。黑潮水域は，魚の “産卵場”といえる。しかし，黑 潮は親潮に比べ餌となるプランクトン類は少なく, 成長期
に入る稚魚や幼魚, また産卵後の親魚は, 春から夏にかけ て餌を求めて北上（索餌北上群）, 親潮に出合う。親潮は, 一般的にいえばプランクトンが豊富で黒潮の $3 \sim 5$ 倍（1 $\mathrm{m}^{3}$ 当たりの葉緑素量は, 黒潮の $0.1 \sim 0.3 \mathrm{mg}$, 親潮 $0.5 \sim 0.7$ mg）もある. 夏に北の海で慨を食べ，成長して肥った魚は 秋から冬にかけて産卵のために黒潮水域へ南下する.

漁場とは，このような北上あるいは南下過程で, 魚群が 多く集中し滞っている場所であって, 暖水渦と冷水渦が接 している潮境部分に形成される。 その間の回遊経路が暖水 ストリーマ (帯状の暖水) や冷水ストリーマ(帯状の冷水) である.さらに，この潮境部分を拡大してみると，小规模 の時計まわりの暖かい渦と, 反時計まわりの冷たい渦が多 く形成されている。 これら小規模渦は, 植物プランクトン が光合成を行うために必要な栄養塩や温度を供給しており, 魚が集まるための慨条件を形成するための原動力となって いる. すなわち，プランクトンの少ない黑潮水域で冷水渦 が形成されれば, 餌が豊富となる。このため, 冷水渦の周 辺部は, 暖水性の魚（カッオ，キハダ等）にとって適温で ある黒潮の中にいながら, 豊富な餌が得られる場所であり 良い漁場となる。あたかも，砂漠の中の“オアシス”の ように, 餌を求めて魚群が集まるのである.これらの生態 を利用して漁場を予測をするのであるが，ここで漁場予測 GISを具体的に述べてみよう. 


\section{2. 漁場と海洋特性}

冷たい親潮水域にある暖水渦は, 暖水性の魚にとって冷 たい海域で生活するための「寄りどころ」である。また, その周辺部には餌も豊富で, 暖水渦は親潮水域へ魚群を運 ぶ“運搬船”の役割をしているといえる。したがって， 寒流系の中の暖水渦の周辺も冷水渦と同様によい漁場とな りやすい. 以上のことを第 1 図の模式図で簡単に示す.人 工衛星から総観的にこのような渦を発見することは, 漁場 を発見することにつながると考えられる. したがって, 渦・ ストリーマ・潮境等の海洋特性と実際に形成されている漁 場との関連が多く解明されることが, 漁場予測にとって重 要である. その一例として, 日本周辺の暖水渦とカッオ・ クロマグロ・スルメイカ漁場の関係を示す. 第 2 図は, 1986年 6 月 12 日の日本周辺の衛星画像をもとに模式化した 漁海況図である. カツオ・マグロ・スルメイカ漁場ともに 暖水渦の中に形成されていることが分かる. 特に, マグロ 漁場は，金華山沖暖水渦の中に形成され，この渦は周囲が 冷水で囲まれているため, マグロはこの中に滞留し, 暖水 渦が「天然の大型定置網」の役割をしていると考えられる.

\section{3. 魚道と暖水ストリーマ}

人が入り込まない山の中で獣のみが通り，自然にできた 道をよく獣道と言う. 海にも魚が通る魚道は存在するので あろうか. おそらくこれは, 帯状に細長く, しかも慨も豊 富で，まさしく魚にとっては，新しい生活の場所へ移動す るための「シルクロード」に匹敵するのであろう．海の中 にこのような道があることをだれも見たことはないと思う。 この道は, おそらくある条件の時に発生し, 他の海洋現象 に比べ, 微細で変動が大きく, 短命であると考えられる. なぜなら, 従来の船舶による調査では全く観測されなかっ たからである。もちろん, この魚道の発見は, 漁場を予測

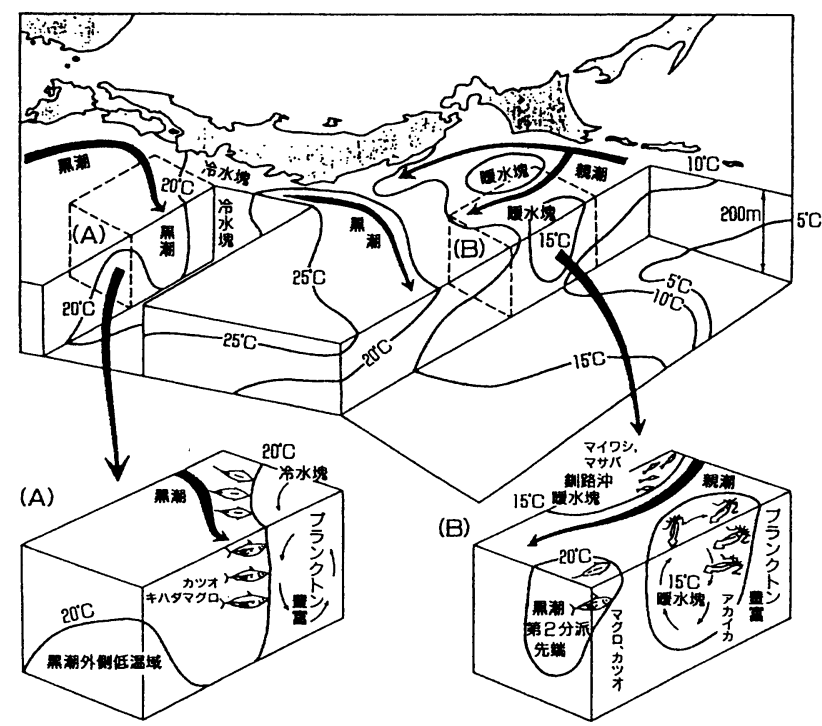

第 1 図 日本近海の海流と魚群の関係を示寸模式的立体図（平野 為石, 1996)
する上にも，また成魚や稚魚が生き残るための良い環境条 件に到達できるか否かにおいて，資源の面からも重要であ ろう.

衛星による水温分布図にマイワシ漁場をプロットしたと きのことである．絶えずつきまとう今までに見たことのな いような微細な水温パターンが目についた。これはいった い何だろう。第 3 図は，1987年，1988年，1990年の三陸初 漁期のマイワシ漁場を NOA A 衛星画像から解析した水温 分布にプロットした図である。1989年の図が抜けているの は，この年のみ初漁期に雲が多く，画像が解析できなかっ たためである。この図から， 3 年とも初期漁場の沖合に細 い帯状の暖水（帯状暖水）が接近していることが分かる. この帯状のものと漁場との間に何か関係があるかもしれな い.また，第 4 図は1987年 5 月21日〜 6 月 1 日まで，衛星 画像から判断された帯状暖水が, 鮫角沖東南東60海里沖合 に接近している状態を示している. 第 5 図に示すとおり, この南側の三陸沿岸から漁場が徐々に北上している気配も なく，5月21日〜27日は目立った漁獲もみられていない. しかし，28日から漁獲が一晚一力統当たり（以下CPUE= Catch/Unit Effort）約 $50 \mathrm{t}$ 急激に好転し，29日にはこ のとき最高のCPUE約 $120 \mathrm{t}$ の漁獲がみられた。これは，2 9日に帯状暖水が接近しており，その先端部に本格的な漁 場が形成されたためであると考えられる．同様に，第 6 図

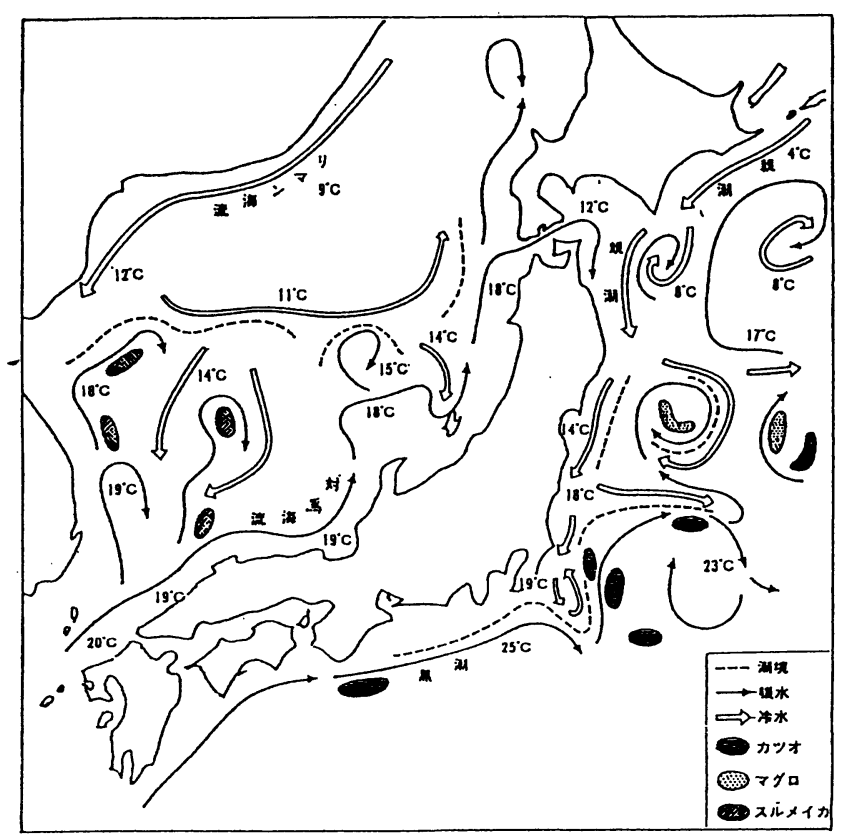

第2図 衛星情報を利用して作成した海況図（1986.6.12）（為

石，1986：提供＝漁業情報サービスセンター)

この図から, 水温情報, 黑潮・親潮や暖水渦・冷水渦など の動的な水塊状況の実態を表す海洋情報が得られ, 将来的に は，リアルタイムで，漁場予測の可能性がでてくるであろう. 黒潮水域は $23 \sim 25^{\circ} \mathrm{C}$ を示し，カッ才漁場となっている。 た，金華山沖には黒潮から分離した大型の暖水塊があって, 周辺部に冷水があるため，暖水塊が天然のマグロの定置網の 役目を果たし好漁場となっている. 
は1989年 6 月12日〜 14日までの帯状暖水が接近している様 子を示したものである．八戸沖の漁場は，13日ごろから帯 状暖水が金華山沖暖水塊から伸び，14日には $11^{\circ} \mathrm{C}$ 台として その形状を明確にしている。この時期，八戸沖で本格的な 漁場が形成されたのは，13日と14日のみである。また，綾 里埼沖の漁場では， $12^{\circ} \mathrm{C}$ 台の帯状暖水が，12〜14日にかけ て綾里埼沖に接近した。ママワシ漁場も綾里埼沿岸に形成 され，11〜 16日までの 1 日平均CPUE約 $60 \mathrm{t}$ の好漁獲がみ られた。

このような例は，他に多くみられており，带状暖水の存 在およびその沖合からの接近がマイワシ魚群の沿岸への来 遊に大きく影響している模様である。これは，大きな発見 である．魚群の来遊と海況要因との関係を明確に示した論 文は，過去非常に少ないので，漁場環境学の大きな発展に つながるものと確信している。 また，この帯状暖水は暖水 (ウォーム) ストリーマとも呼ばれ, 衛星画像が解析され るようになって初めて, 発見された現象である.ささらに,
これは新しい暖水渦の発生, 暖水渦から暖水渦へ熱を補給 する役割を持っていると考えられる。このため, 海洋物理 学的にも非常に興味深い現象とされている.

海況の微細かつ短期的な変動と沖合魚群との関係を解明 するためには，航空機の調査が極めて適している，過去の 航空機観測資料を検討してみたところ，1982～91年の 5 〜 7 月の10年間に東北海域での調査は合計 23 回行っていた. 本調査では, 調査員が熟練の同一の人物であり, 調査期間 は $5 \sim 6$ 月のマイワシの北上期で, 時刻も10〜14時頃に限 定し, 晴天日で風の弱いときのみ実施したことから，発見 率の変動は小さいとみなされる。 I R T （熱赤外放射温度 計）による水温分布図を描いてみたところ，暖水ストリー マが意外に多く観測されていることが分かった（第 7 図）. 第 8 図は，暖水ストリーマの模式図である．暖水ストリー マ内外の魚群の出現頻度分布状態を検討してみたところ, 暖水ストリーマとその周辺に魚群が全部で566群も発見で きたのは驚きであった，暖水ストリーマを，先端部，中間
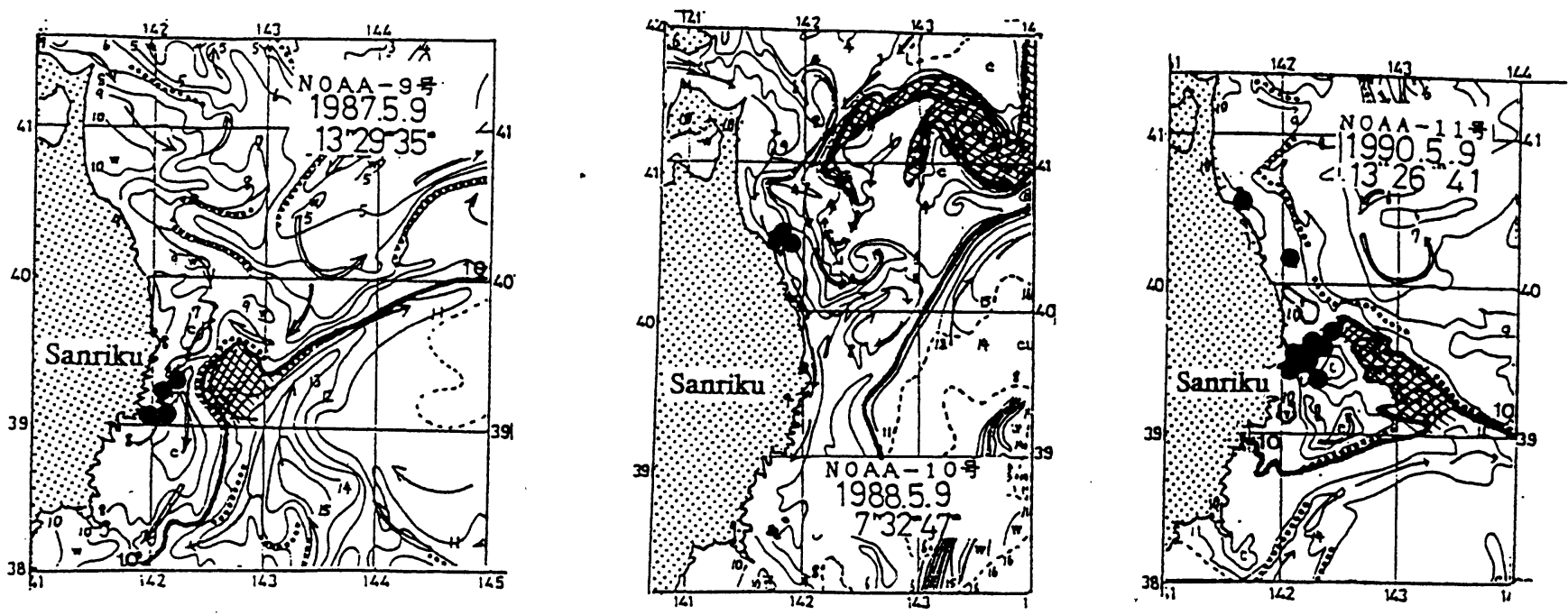

\section{warm streamer sardine fishing grounds}

第 3 図三陸初漁期マイワシ漁場と暖水ストリーマとの関係（左から1987年，1988年，1990年）

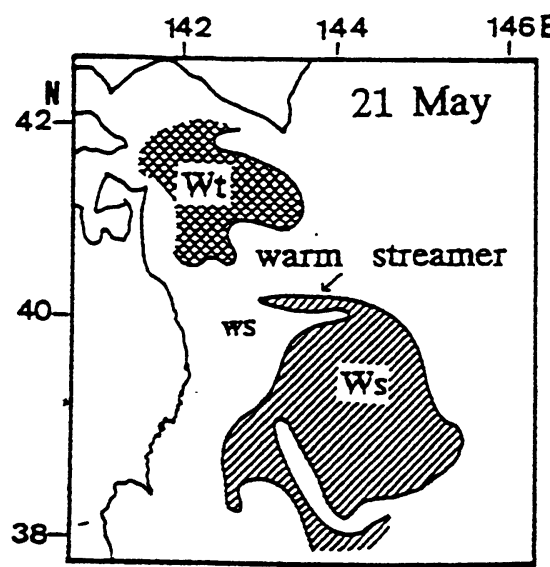

generation stage

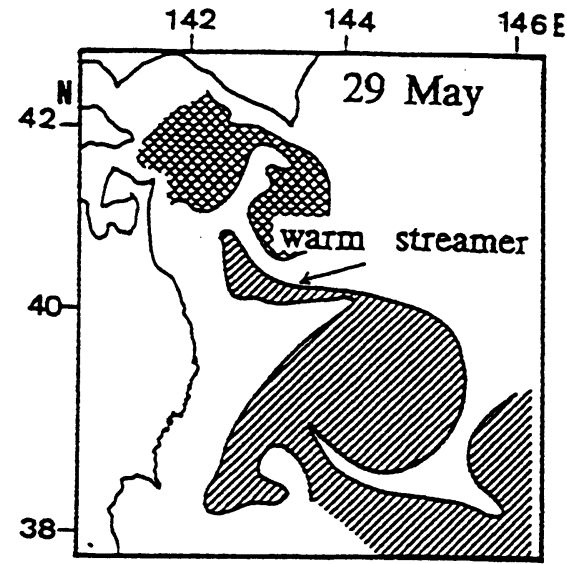

developping stage

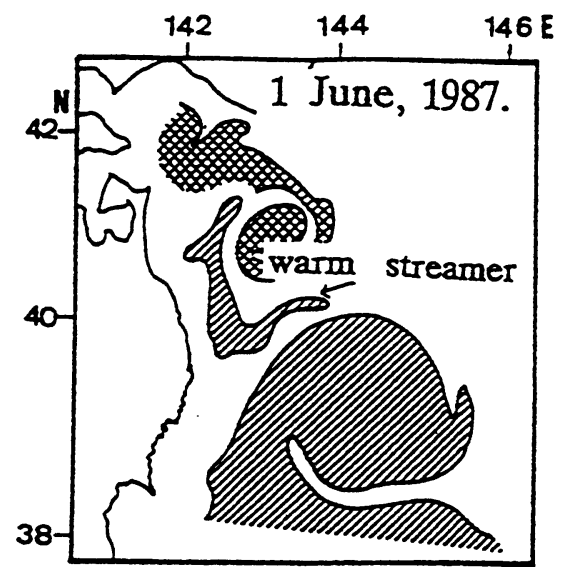

decaying stage

第 4 図＼cjkstart暖水渦から派生する暖水ストリーマが津軽暖流域へ取り込まれる状態を示した模式図（本澤他，1988） 


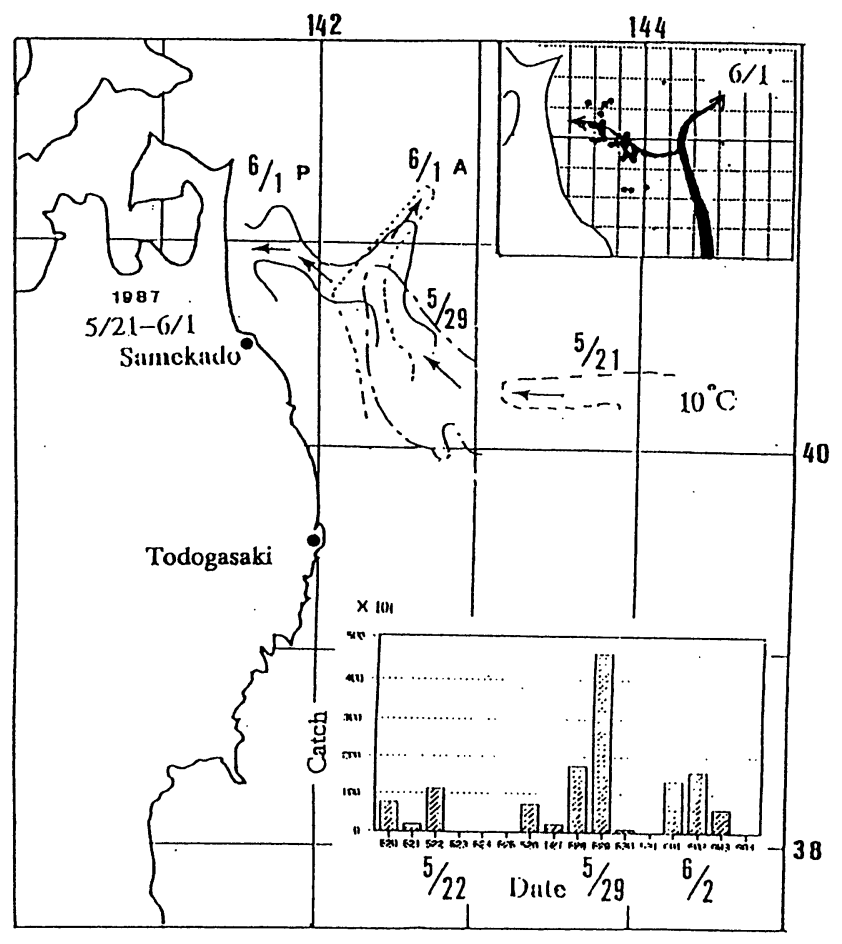

第 5 図 暖水ストリーマの接近とマイワシ漁場の形成および漁獲 量との関係（1987年 5 月21日〜 6 月 1 日）

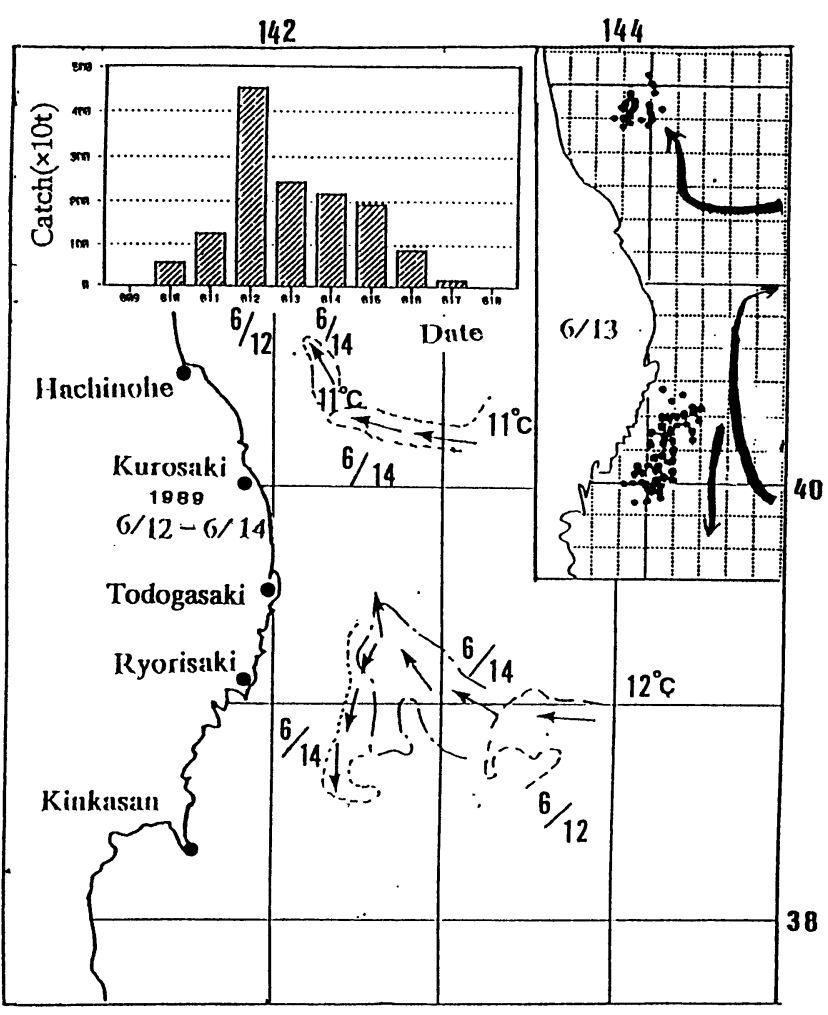

第 6 図 暖水ストリーマの接近とマイワシ漁場の形成および漁獲 量との関係（1989年 6 月 12 日〜14日）

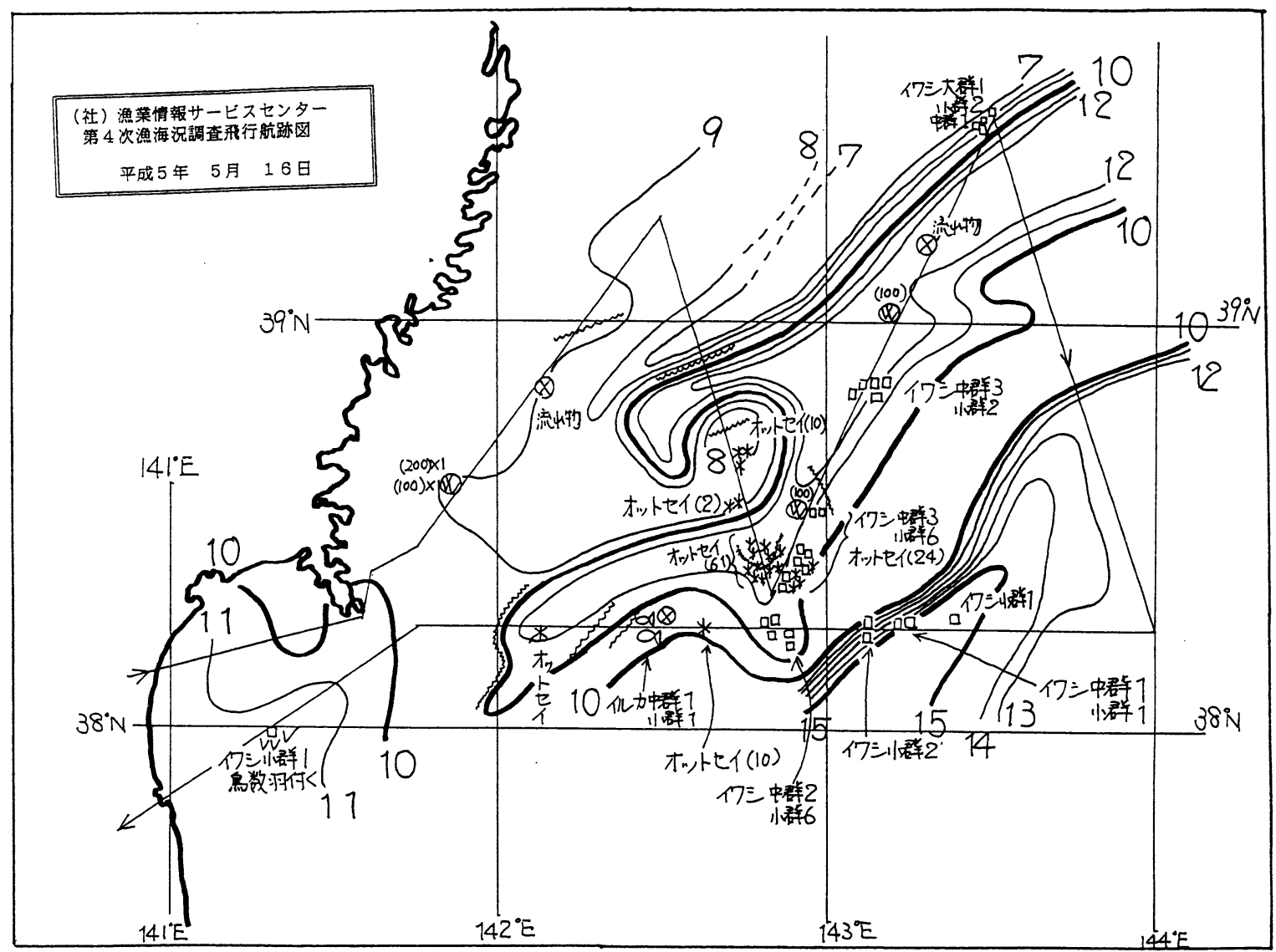

第 7 図 航空機調査による水温分布および魚群分布の結果（1993年 5 月16日） 
部・根元部の内側・外側（外側の範囲は暖水ストリーマの 周辺部で, せいぜいストリーマ幅の 3 分の 1 程度の距離内) に分けた。 その結果, 暖水ストリーマ周辺の暖水側（スト リーマの内側）と冷水側（ストリーマの外側）の発見数を 比較すると，暖水側 $91 \%$ (516群), 冷水側 $9 \%$ (50群) と 暖水側に多く分布している．また，先端部・中間部・根元 部での魚群密度を比較すると, 先端部では全体の $63 \%$ （3． 16群／区画）で最も多く，ついで中間部の $26 \%(1.27$ 群／ 区画)，根元部の $11 \%(0.57$ 群／区画）である。先端部の 出現率が最も高く, 中間部の約 3 倍, 根元部の約 6 倍も分 布していることが分かった. とにかく，暖水ストリーマの 中は, マイワシ群が多いことが明確に示された.

以上のことから, 魚群が回遊するためには暖水ストリー マが魚道の役割を果たしている可能性が強くなってきた

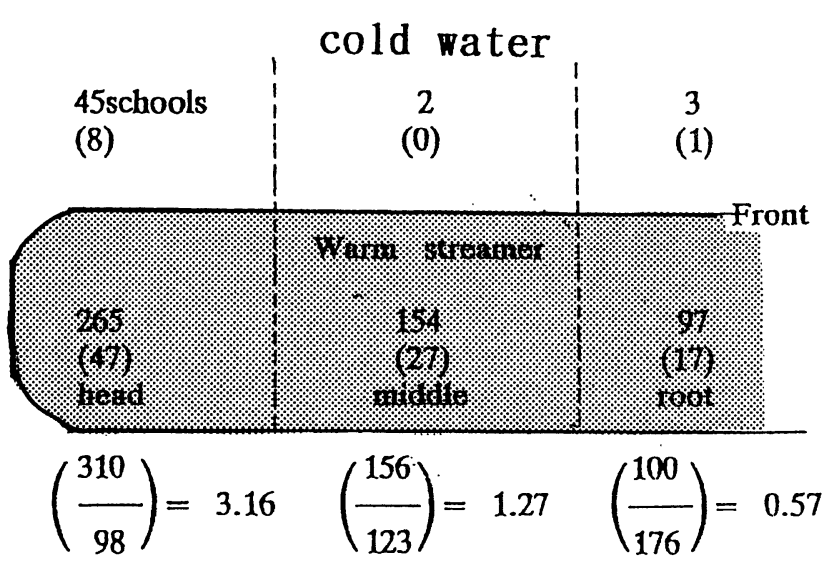

第 8 図 暖水ストリーマ (網目印). 3 つの部分に分けて, 航空 機から発見されたマイワシ群数（括弧内は\%), 出現率（発 見魚群数／観測区画 : 図の下の括弧つき割り算).
(第 9 図).このように，暖水ストリーマの図（第10図）は, 沿岸の漁場予測に有力な手段となることがわかった.

\section{4. 漁場と水温図}

人工衛星から, 1 尾 1 尾の魚群をみることは, 現在のセ ンサ技術から無理である．しかし，魚群が生息している環 境を捉えることは十分に可能である. 魚を取りまく環境は, 水温・塩分・密度・水色・水面の高さによる海流などGIS としての要因が多くある。この中で衛星りモートセンシン グで, 実用的な段階に入っているのは水温である. 水温と 魚群との関わりは, 魚が変温動物であり, 住んでいる水の 温度によって体温も変動し, その生理活動に影響を与える ことから, 最も基本的なものとして重要である. また，水 温の高低は, 魚の来遊や産卵期, 産卵場にも影響する。例 えば, マイワシ資源は, 黒潮と沿岸水との微妙な変動によっ て，魚の慨となるプランクトンにも影響し，わずか $9000 \mathrm{t}$ が400万 $\mathrm{t}$ にも増大した例がある。このように産卵場の水 温は，資源にも影響を与えている。漁場形成に関しても， 第一に「適水温」という考え方で, 魚は魚種により時期に より，定まった水温範囲で生活している，漁業者の話に必 ず漁獲した時の水温を入れるのはこのためである。第二に 日本近海においては, 魚の回遊に直接関係のある暖流・寒 流の離接岸, 魚が集まって漁場となる潮境, 暖冷水の渦, 冷水の湧昇, 暖水（冷水）ストリーマなどは, 水温分布を みれば判断できるのである。このように，適水温により魚 の分布が判断でき, 海洋特性により集群や移動方向が判断 できるので，水温図は重要である.

\section{5. 漁場と水色図}

水色は昔から経験の深い漁業者の間では，漁場判定の目

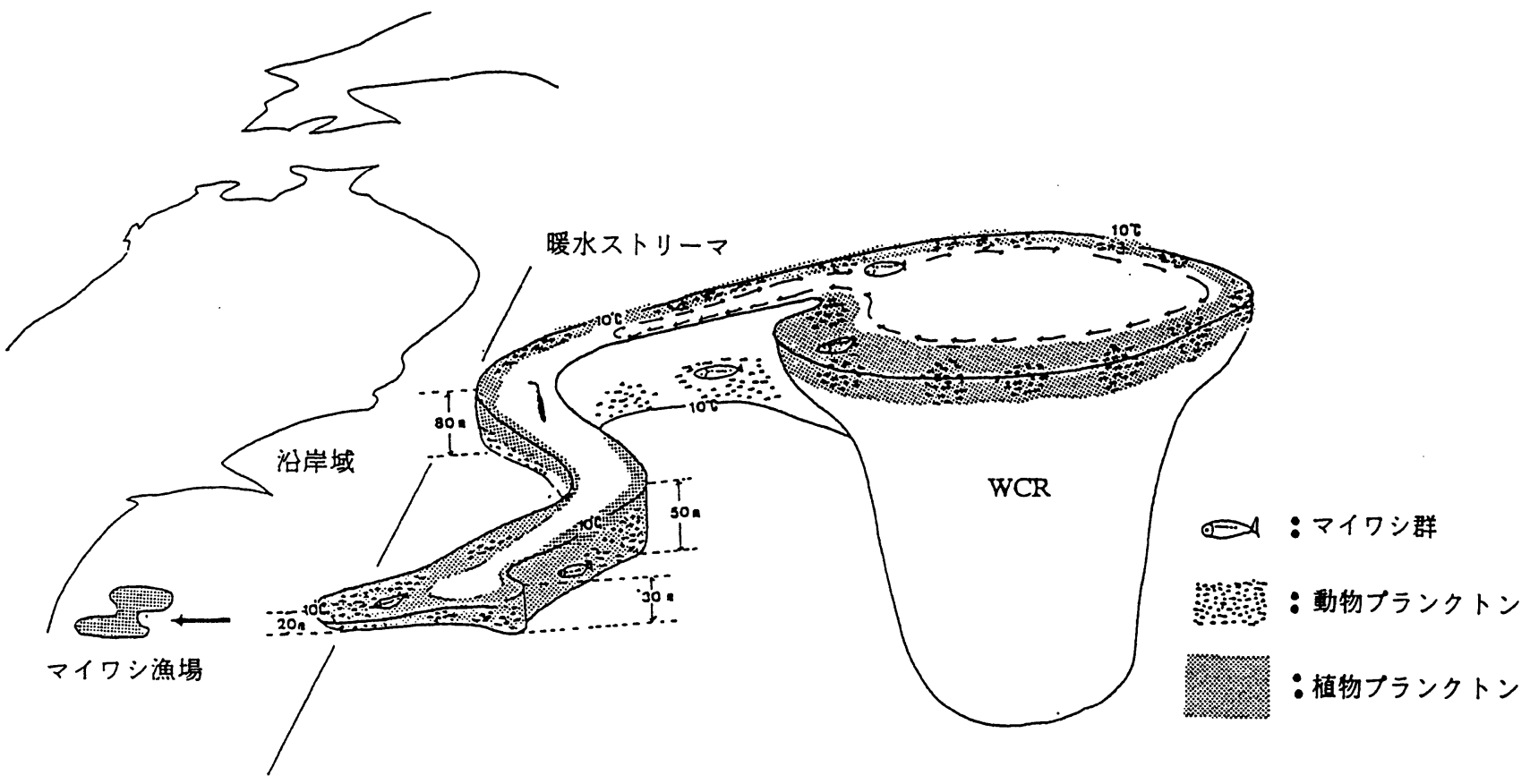

第 9 図 マイワシ群が沖合暖水渦から沿岸へ回遊するための魚道の概念図（WCR: Warm-core ring） 


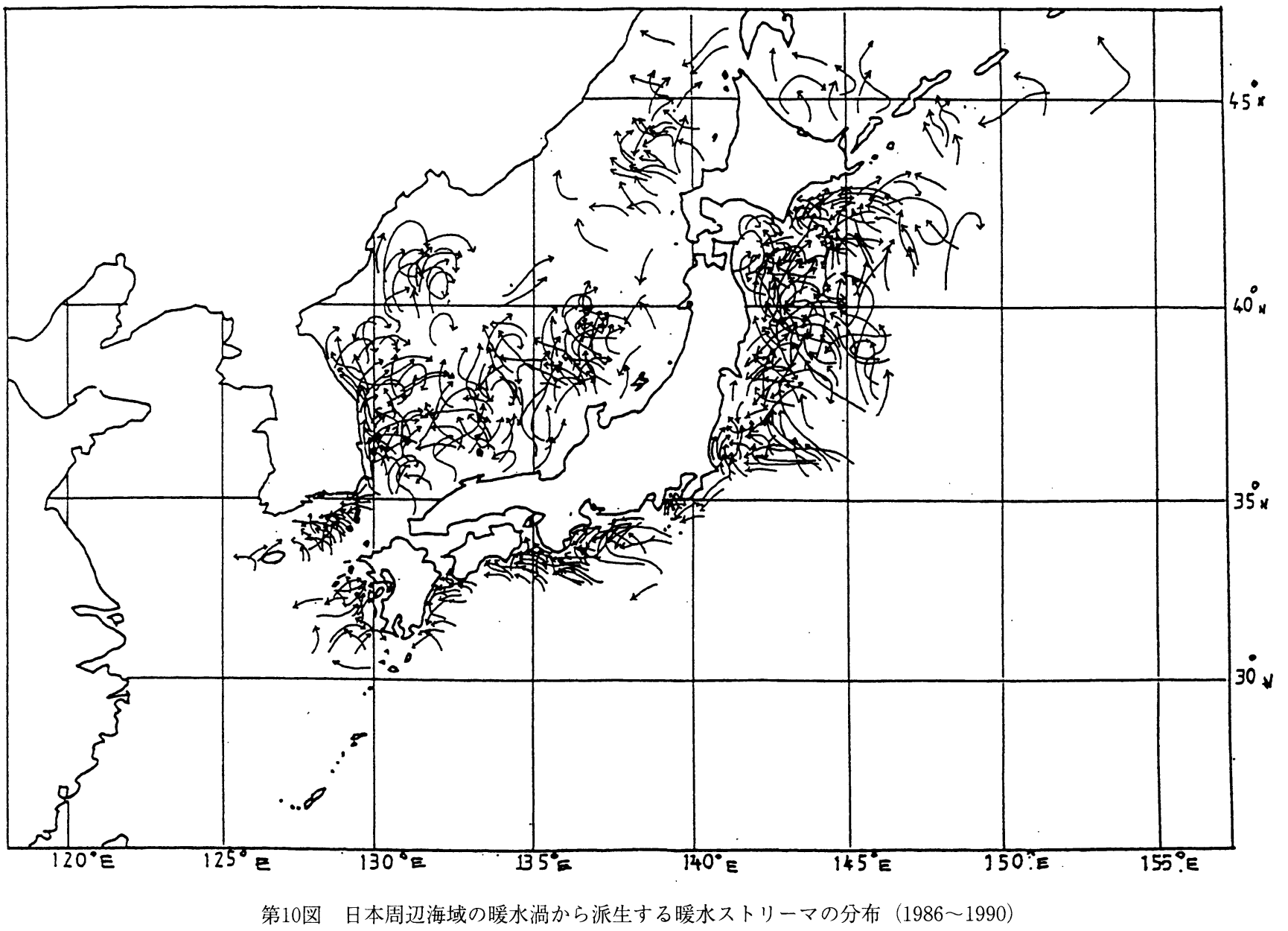

安として使われていた。また，水色は潮目や水塊の判別に も役立つ。夏に日本近海では表面水温が一様に高くなり， 水温差がなくなるため，水塊の判別ができなくなったとき， この判別を水色で行うことも考えられる.

海の水色は，一体何を意味するのであろうか．赤潮や濁 水の分布のようにはっきり色がついている場合は別だが, 海にはいろいろの色素体があって大変むずかしい問題となっ ている．我々が海岸に立って海を見たとき海が青く見える といっても，天候や時刻によってかなり違うことは，いう までもない. すなわち, 海中からの光の色と, 海面で反射 された空の色とが混じったものを見ているのである。した がって，水色を測定する時は，この二つを分離することが 大事な問題である.

水色はすべて太陽エネルギーに依存している．可視光線 の中で木の葉が緑色に見えるのは，7色の太陽光のうち特 に緑色の部分がよく反射されるからである. この他の 6 色 の光と赤外線は吸収され，木の葉の熱となる。このまま持 続すると，木の葉が熱を吸収し続け，熱くなるが，あまり 熱くならないのは，逆に熱を放射し，バランスを保ってい るからである。この放射を輻射ともいい，赤外線の形で宇 宙に戻る。

過去、海洋の水色（クロロフィルー $\mathrm{a}$ の分布）を観測し た例は，米国衛星ニムバスー 7 号のセンサC Z C S が唯一
である (JAFIC，1991）。この画像に同日の漁場データを プロットすることにより，水色と漁場との法則性を見つけ 出すことが必要である。ここで, カッオとサンマ漁場の検 討例を初期段階ではあるが紹介する.

(1) カツオ竿釣漁場（第11図）

カツオ漁場は, 1980年 6 月 5 日と同年 9 月18日の水色画 像で検討した。その結果，黒潮系の北上暖水に形成され， クロロフィル值も $0.10 \sim 0.42 \mu \mathrm{g} / \ell$ と少ない海域にみら れた.

(2) サンマ棒受網・アカイカ釣漁場（第12図）

1980年 9 月18日の画像を利用した。 サンマ漁場は，親潮 の先端部で, クロロフィルー $\mathrm{a}$ が $0.75 \sim 3.20 \mu \mathrm{g} / \ell$ と多 い海域にみられた。アカイカ漁場は, 釧路沖暖水渦の中に 形成され，クロロフィルー $\mathrm{a} は 0.08 \sim 0.24 \mu \mathrm{g} / \ell$ と少な い側に相当していた。

以上の魚種以外に, クロマグロ・アカイカ・マサバ・ビ ンナガ等を検討し，適水色スペクトル図（第13図）を作成 した.これにより，衛星による水色分布が分かれば，魚群 探索に利用できる可能性ができ，水色図は漁場予測に役立 つのである。

\section{6. 漁場と適水温・適水色合成図}

「適水温」という概念は, 水温観測データが容易に入手 


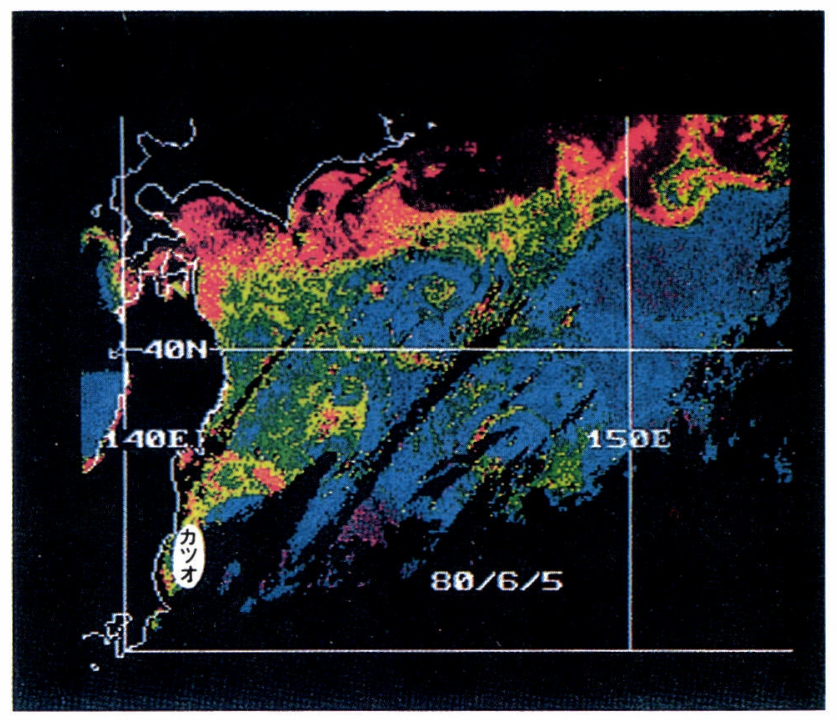

第11図 クロロフィルー $\mathrm{a}$ の分布とカツオ漁場との関係

カツオ釣り漁場（北上期：1980年 6 月 5 日）

(1)黑潮続流域と沿岸水との境目に形成

(2)黑潮続流域内のクロロフィルの少ない海域に形成.

(3) $0.24 \sim 0.42 \mu \mathrm{g} / \ell$.

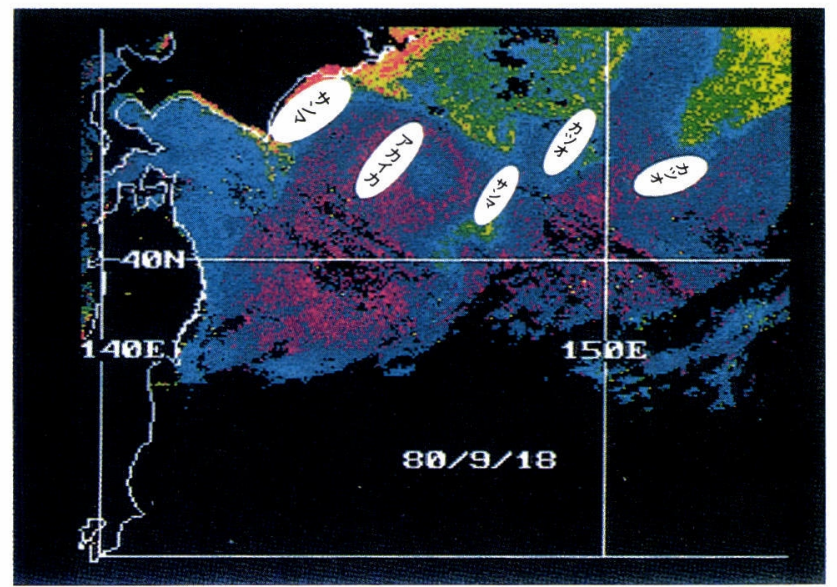

第12図 クロロフィルー $\mathrm{a}$ の分布とカッオ竿釣り, サンマ棒受網 拉よびアカイカ釣漁場との関倸

カツオ竿釣り漁場（南下期：1980年 9 月18日）

(1) 沖合北上暖水域内 $\left(17 \sim 20^{\circ} \mathrm{C}\right)$

(2)袋状クロロフィルー - a の少ない海域: 西側の漁場は水色 前線で，東側の漁場は水温前線で制限されている.

(3) $0.10 \sim 0.18 \mu \mathrm{g} / \ell の$ 範囲.

サンマ棒受網漁場

(1)親潮第 1 分枝内と第 2 分枝内の先端に形成されている.

(2)相対的にクロロフィルの多い海域に沿って形成されてい 子.

(3) $0.75 \sim 3.2 \mu \mathrm{g} / \ell の$ 範囲.

クロロフィル $-\mathrm{a}$ の濃度：～赤 $\geqq 1.5(\mu \mathrm{g} / \ell)$

$1.5>$ 黄 $\geqq 0.5$

$0.5>$ 緑 $\geqq 0.25$

$0.25>$ シアン $\geqq 0.15$

$0.15>$ 青 $\geqq 0.05$

$0.05>$ マジェン夕

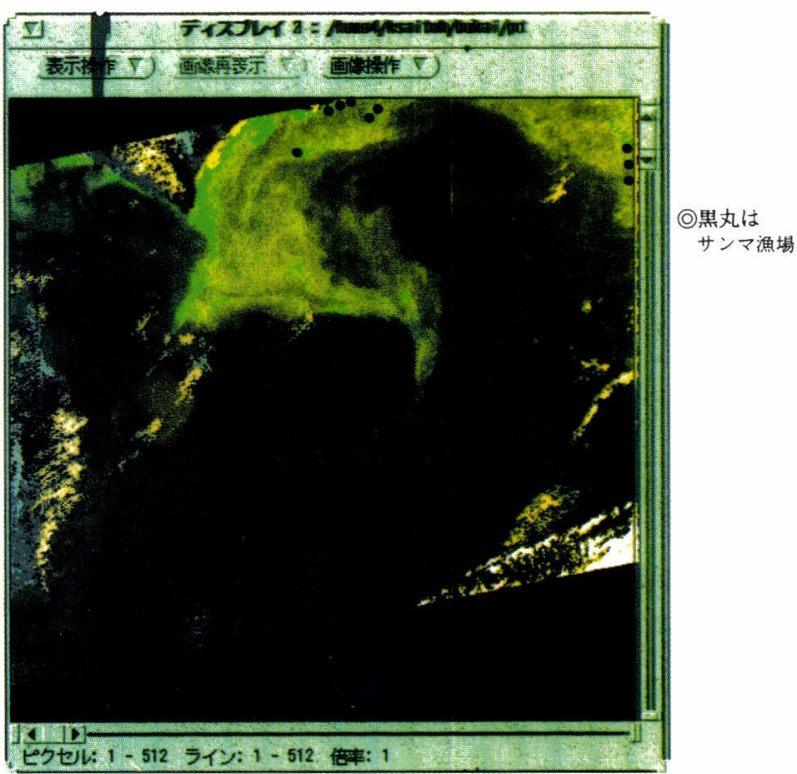

第14図 NIMBUS－７ CZCSによるサンマ適水温と適水色の合 成画像（黒丸はサンマ漁場：1981年 9 月17日）

黄色の適水温 $\left(9 \sim 15^{\circ} \mathrm{C}\right)$ と緑色の適水色 $(0.75 \sim 3.20 \mu \mathrm{g}$ （）の重なった黄緑色の海域にサンマ漁場（黒丸）が形成 されている。釧路や花咲港に近い海域に漁場が見られるが， 襟裳岬南方も漁場形成の可能性が大きい。適水温带（黄色） は広く分布して扮り，漁場を探査するには，適水色（緑色） が必要.

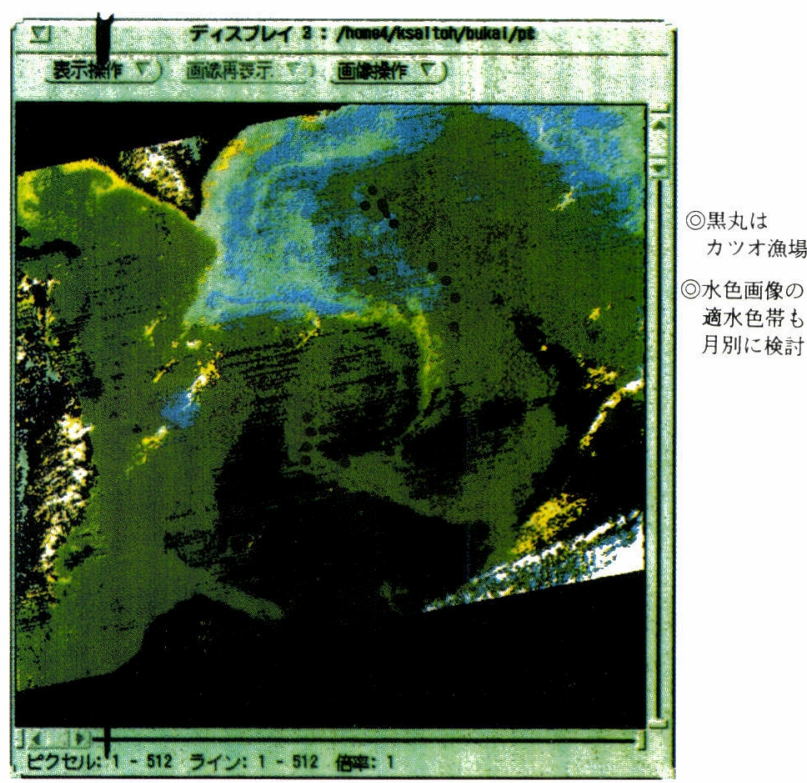

第15図 カッオの適水温と適水色の合成画像（黒丸はカッオ漁場： 1981年 9 月17日)

カッオの適水色（青色：0.10 0.42 $\mu \mathrm{g} / \ell$ ） は広く分布 し，漁場の選定には広い海域の探索が必要となる。これに黄 色の適水温 $\left(19-20^{\circ} \mathrm{C}\right)$ を重祖て表示すると, 青色と黄色の 重なった緑色の海域に選定できる。カッ才漁場（黒丸）はほ とんどが緑色の海域に分布していることが分かる。特に暖水 塊に緑色が渦状に分布し，カッオ漁場も渦状に分布している ことが興味深い 


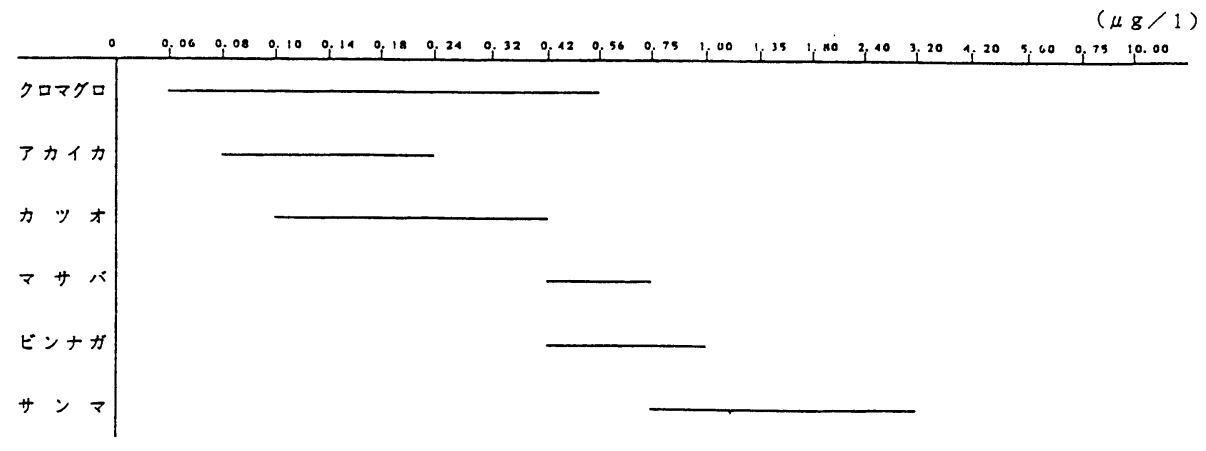

第13図 主要魚種適応クロロフィルー $\mathrm{a}$ 濃度スペクトル

疑似カラー画像と同日の漁場をプロットすることにより，魚種によりそれらが好む クロロフィル量に差があることが分かった．例えば，クロマグロは0.06〜0.56 $\mu \mathrm{g} /$ $\ell$ と少ないが比較的幅が広く, アカイカは $0.08 \sim 0.24 \mu \mathrm{g} / \ell$ と少なくて幅も狭い. 一方, サンマは $0.75 \sim 3.20 \mu \mathrm{g} / \ell$ とクロロフィルの多い海域を好む。 このことから， 魚種別に適応水色が存在し, 漁場探査の指標となると考えられる.

可能なことから，過去魚群探索の指標として利用されてき た（宇田，1940）。一方，近年人工衛星によりクロロフィ ルー a の画像が容易に入手可能となり, 浮魚の漁場をプロッ トすることにより，魚種によって好きなクロロフィルー $\mathrm{a}$ 量の分布帯があることがわかり,「適水色」という概念が うかび上がってきた(JAFIC，1992）。これら，「適水温」 と「適水色」の 2 つのアクターを合成することによって, 漁場探索を容易にする新しいGISが考えられる。

第14図は1981年 9 月17日の画像に，サンマの適水温（9 $\left.\sim 15^{\circ} \mathrm{C}\right)$ と適水色 $(0.75 \sim 3.20 \mu \mathrm{g} / \ell)$ とを合成した画像 である。これに同日（1981年9 月17日）のサンマ漁場をプ ロットするすると, 適水温帯と適水色帯が重なった海域に 漁場が形成されている. すなわち, 適水温・適水色を同時 に満たす海域がサンマにとって最良の漁場といえよう。襟 裳岬南方にも重なり合った海域がみられるが, 有望な漁場 予測海域と考えられる。しかし，この時期の漁港である釧 路や花咲港に近い海域に漁場が形成されるのは, 鮮度保持 のため当然の帰結と言えよう.

第15図は同じ画像から，カツオの適水温帯である19 20 ${ }^{\circ} \mathrm{C}$ と適水色帯である $0.10 \sim 0.42 \mu \mathrm{g} / \ell$ とを合成したもの である。サンマ漁場と同じく同日のカッオ漁場をプロット すると重なった海域に漁場がみられることがわかった．特 に三陸沖暖水渦の海域では, カツオ漁場も渦状に分布して いるので興味深い.

以上のように，2つのファクターを合成した「適水温・ 適水色合成図」は漁場予測GISとして有効であるとともに, 潮境・渦・ストリーマなどの海洋特性を付加することによっ て, 将来より良い精度を出す新しいGISとして今後注目さ れる。

\section{7.おわりに（漁場予測GISへの諸要因）}

以上述べてきたGIS要因は一部であり, その他にも漁場 を予測するためには多くの要因がある，第16図には将来漁
場予測GISの要因を考えられる範囲内で列挙してある。全 ての要因は相互に関連し，ループ状につながっている。ま ず第1に，(1)過去の蓄積データによるGISとして考えられ るのは，(1)漁期情報，(2)漁場位置情報，(3)魚種情報，(4)漁 獲高情報, (5)動植物プランクトン情報（飭情報図: 水色図, クロロフィル図, 湧昇域図), 6海洋特性情報（適水帯図, 水塊配置図，フロント分布図）などがある。この過去の蓄 積データは，従来漁業者の経験によって裏付けられた勘に

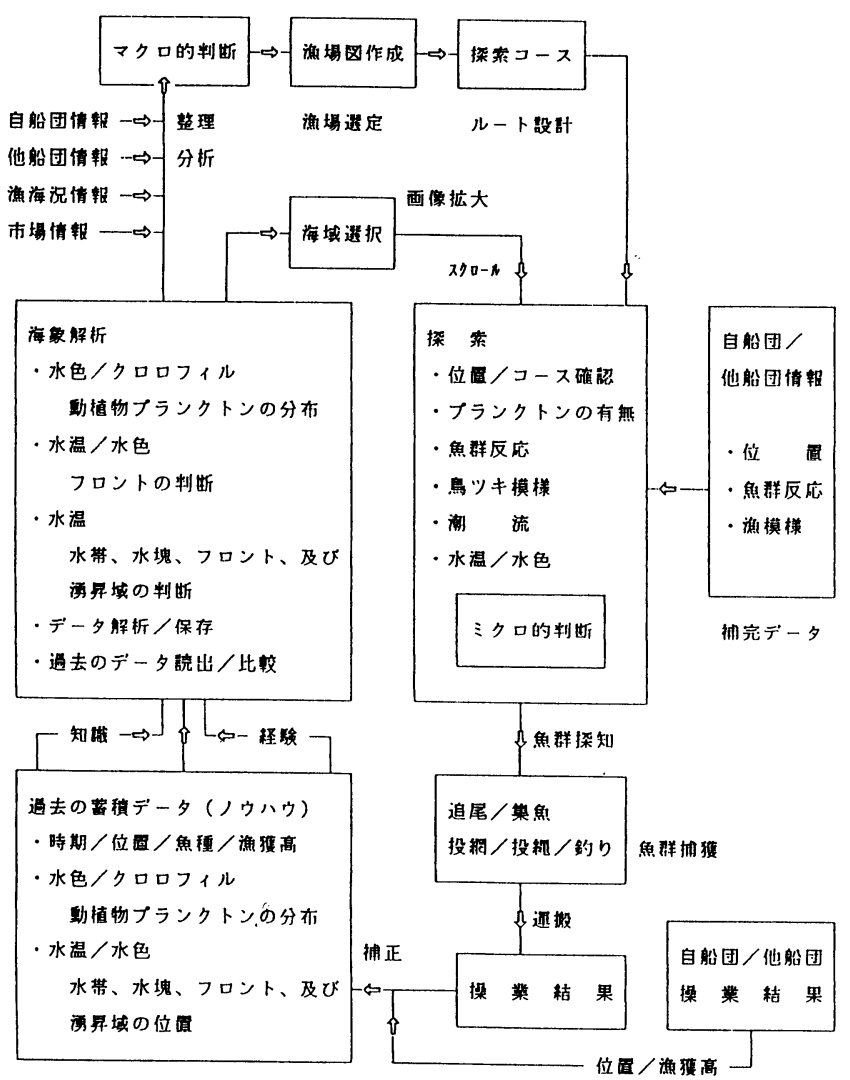

第16図＼cjkstart漁場予測GIS諸要因 
よるところが多く, 今後はGIS情報として将来へつなげて いかなければならない部分である，第 2 に，(2)漁場予測を するための船舶・衛星観測デー夕による海象解析GISであ る.これには, (1)水温分布図, (2)水色分布図 (透明度分布 図), (3)海流分布 (潮流分布) 図, (4)フロント分布図, (5) 市場情報, (6)船団間暗号情報, (7)上記(1)の蓄積データの解 析図の種類が考えられる. 第 3 に(1)と(2)にもとづく漁海況 予測（予測水温分布図，漁場予測図など）である.

第 4 に漁場形成可能海域まで漁船を運んだ後に, 魚群を 探索するための探索情報GISである。これには，自船の魚 群探知機器等による(1)位置・コース, (2)エコーサウンダー によるプランクトン情報, (3)スキャニングソナーによる魚 群反応情報, (4)鳥群レーダによる鳥群情報, (5)A D C P (Acoustic Doppler Current Profiler)による海流（潮流） 図，6自船観測による水温・水色鉛直分布図などがある. これにより，魚群を発見し漁獲する．漁獲した時の操業結 果のデー夕は, 第 1 の)蓄積デー夕に蓄えられ, 再び同じ 回路をまわり時間の経過とともに漁場予測精度が高められ るのである.

\section{文献}

漁業情報サービスセンター（1987）衛星から海と漁場をみ る．漁業者のための衛星情報の見方使い方.

漁業情報サービスセンター（1991～1993）平成 $2 \sim 4$ 年度 サテライトデータ利用システム開発事業報告書.
漁業情報サービスセンター（1995・1996）平成 $6 \cdot 7$ 年度 水温水色衛星デー夕活用システム開発事業報告書.

平野敏行 - 為石日出生 (1996). 海流 - 潮境 - 海の渦と魚 群. 日本列島をめぐる海, 堀越増興 - 永田 豊・佐藤 任弘・半田暢彦著, 日本の自然 7 , 岩波書店, pp.111-120.

本澤雅彦 - 為石日出生 - 本原興平 - 大塚一志 - 石野 誠 （1988）衛生画像から識別した東北海域におけるウォー ムストリーマの挙動. Journal of the Tokyo University of Fisheries, vol.75, no.2, pp.433-441.

水産電子協会（1993）平成 4 年度ADEOS/DTL受信 装置の設計検討. 宇宙開発事業団業務委託成果報告書.

為石日出生（1985）人工衛星を利用した魚群の探索. 計測 と制御, vol.24, no.3, pp.209-218.

為石日出生・杉本隆成（1993）東北海域におけるマイワシ の北上回遊と接岸に暖水渦と暖水ストリーマの果たす 役割一航空機調査から一. 水産海洋研究, vol.58, no. 1, pp.1-8.

為石日出生・杉本隆成（1993）暖水ストリーマと漁場形成. 月刊海洋, vol.25, no.2, pp.105-111.

為石日出生 (1994) 衛星・航空リモートセンシングの水産 への応用一宇宙から海と魚を考える一. 水産振興, 東 京水産振興会, $318 \mathrm{p}$.

宇田道隆（1940）魚群集散の原理について. 植物及び動物, vol.8, no.8, pp.1379-1386, vol.8, no.9, pp.15231532.

\section{要 旨}

\section{水産情報とGIS}

: 為石 日出生

漁場予測は計画的漁業にとって最も重要である. GISはこの目的に対して最も有力な手段の1つであるが，これま でにはあまり利用されていない. 資源の状態, 漁場の環境, 経済的効果など, 漁業に関する多次元的情報の取り扱い は，漁場予測のためにはさけて通れない．GISにもとづく漁場予測は常にこれら以外の多くの要因を含んでいる．例 えば, 漁場は生物的要因と海の物理的・化学的環境の間の複雑な相互作用の下で形成される.

キーワード : 漁場予測, 水産情報, 海洋特性, 魚道, 暖水ストリーマ 